\title{
Primary Education Innovation In Industrial Revolution 4.0 Vs. Professional Teacher
}

\author{
Sola $^{1}$, Ermi $^{2}$ \\ \{ermisola18@gmail.com ${ }^{1}$,eminpatta@gmail.com $\left.{ }^{2}\right\}$ \\ ${ }^{1}$ Faculty of Education and Teacher Training, FIP UNM, Indonesia \\ ${ }^{2}$ Alauddin State Islamic University, Indonesia
}

\begin{abstract}
Technology" is an essential word today. Technology helps people much. Technology makes everything easier, faster, and much more accurate. Many people depend on technology. Today's era is called millennial. It's believed that millennial era means the end of the world. In this era, the dynamic of world change is signed by what it is called industrial revolution 4.0 (IR 4.0). In accordance with education, IR 4.0 is characterized by innovation-process of making changes to something established by introducing something new with a better result. To create innovation, students should have curiosity, creativity, collaborative, and social/physical interaction. Thus, it needs professional teachers. Professional teachers are responsible to train students to master those skills and or competences by taking the advantages of technology--special feature of IR 4.0--ethically. Meanwhile, the teacher's role is as a facilitator or mentor for the students and treat them as individuals.
\end{abstract}

Key words: innovation, education, professional teacher

\section{Introduction}

Today, many people talk about industrial revolution (IR) 4.0. Conceptually, IR 4.0 is a new vision of today's rapid change where many human works are replaced by machines. Many seminars and conferences are held to discuss IR 4.0 included its relation to education. In fact, education is one of the implication of IR 4.0. Facing the education in IR 4.0 learners not only learn skills and knowledge but also identify the source to learn those skills and knowledge (Fisk in Hussin; 2018; 1). In this case, peers become very significant during the process of learning. The students learn together and from one another, while the role of the teachers is mostly facilitators or mentors.

Generally, innovation is the process of making changes to something established by introducing something new (pcf4.dec.uwi.edu>innovation). Or, doing something fresh (new, original, or improved) that creates value (http://www.freshconsulting.com/what-isinnovation). From those two concepts, when it is related to education, educational innovation means a procedure or method of educational activity that differs significantly from established practice and is used to increase the level of efficiency in a competitive environment (Mykhailsyin, Kondur, Serman; 2018). Thus, educational innovation is dealing with a new and valuable procedure or method used in the teaching and learning process to create or introducing something new. When it is related to the application in the classroom, it can be seen that collaborative classroom encourages innovation. It is because the students have to 
discuss and work with others who may be different from them in many things, such as they are different from their beliefs, behavior/character, and of course their background.

A professional teacher/educator is crucially needed in the teaching and learning process in the era of IR 4.0. He/she functions as a facilitator or mentor who will guide students to create innovation. He/she has to prepare students to be familiar with the technology and take advantage of it. $\mathrm{He} / \mathrm{she}$ has to encourage students to be curious, creative, collaborative without paying attention to any differences, and participative in social and physical interaction without forgetting their unique individualism.

\section{Discussion}

\section{EDUCATION AND INNOVATION IN INDUSTRIAL REVOLUTION 4.0 (IR 4.0)}

\section{a. Definition of Education Innovation IN IR 4.0}

Innovation is defined as creating value from ideas (http://www.downes.ca/post/67693). Innovation is also an idea or a practice perceived as new by the adopter. It refers to any new idea, product, approach, or an action plan (https//id.scribd.com/doc). Innovation is also doing something fresh (new, original, or improved) that creates value (http://www.freshconsulting.com/what-is-innovation). Another definition is that innovation is the process of making changes to something established by introducing something new (pcf4.dec.uwi.edu>innovation). Educational innovation is the tryout of the strategy or approach, developed after systematic investigation so as to improve the process of education. Or the process of improving education by adopting newer technique and strategies (which are so far unknown) in educational objectives, teaching-learning method and material, function and functional relations, curricula as well as organizing new bodies (https//id.scribd.com/doc.). Mykhailsyin, Kondur, Serman (2018) say that educational innovation means a procedure or method of educational activity that differs significantly from established practice and is used to increase the level of efficiency in a competitive environment. From those ideas, it can be concluded that innovation is doing something existed or something new in a different way with a better result. Educational innovation is dealing with trying out something with the new strategy or approach in order to improve the process and or result of education to become better. In a simply way, it can be said that educational innovation is dealing with new and valuable procedure or method used in the teaching and learning process and create something new and might be interesting.

Talking about education and innovation in IR 4.0 means a new vision of today's rapid change where human works are replaced by machines. Many seminars and conferences are held to discuss IR 4.0 included its relation to education. In fact, education is one of the implication of IR 4.0. Facing the education in IR 4.0 learners or students not only learn skills and knowledge but also identify the source to learn those skills and knowledge (Fisk in Hussin, 2018; 1). In this case, peers or partners is important during the process of teachinglearning because the students learn together and get information from one another. Teacher, in the other side is just facilitators, assists students when it is needed. In relation to the application in the classroom, this kind of collaborative work among students will encourage them to create something new and make their learning valuable. Then they do innovation. It is because the students discuss and work with others who may be different in many things, such as beliefs, personality/character, and family background, etc. 


\section{b. Characteristics of Education in IR 4.0}

Talking about education in the era of industrial revolution 4.0 is not as easy as what people think about. Education in the era of industrial revolution 4.0. has to adjust itself with the community that change dynamically and rapidly. There are nine trends related to education in IR 4.0 (Fisk in Hussin, 2018; 1-2). Those are:

\section{Learning can be taken place at anytime and anywhere}

In such dynamic change and fast information communication, e-learning is a useful tool especially for remote area, self-paced learning. Flipped classroom approach is also useful because it allows interactive learning in the classroom, while the theoretical parts can be learned outside the class time.

\section{Learning will be personalized to individual students.}

Since learning is personalized to individual, a more difficult task will be given to the students when they master a certain level of subject matter. More practices will be provided if the teacher think they students need them. It is recommended if the teacher gives positive reinforcements in order to promote positive learning experience and boost students' confidence about their academic abilities.

3. Students have a choice in determining how they want to learn

Education in IR 4.0, there is a freedom for students to choose the learning tools or techniques that they prefer during the process, like blended learning, flipped classroom, etc. It does not matter when the learning outcomes of a course are preset by the institutions/bodies in charge of the curriculum.

\section{Students will be exposed to more project-based learning}

In education IR 4.0 era, partners/peers are an important part during the process of learning. Students are working and getting together with their friends without caring of differences among them. This way of "collaborative learning" encourage students to apply their knowledge and skill. At the end will result innovation. Thus, giving students a couple of short term projects are useful because they can practice their skill in time management, organization and collaborative work are useful in their future academic careers.

\section{Students will be exposed to more hands-on learning}

By doing hands-on learning through field experience like internships, mentoring projects and collaborative projects related to their subject, students are motivated to acquire new skills that involve human face-to-face interaction/communication.

\section{Students are trained to apply their knowledge to data interpretation}

In this technological 4.0 era, the students essentially should know how to take the advantages of the technology. They have to understand and have knowledge about the value of the technology. Then, they should have skills how to use or apply their knowledge to make inferences based on sets of data logically. 


\section{Students will be assessed differently}

In this case, one of the teacher's responsibility is students' factual knowledge that can be assessed during the learning process. However, the application of the knowledge can be tested when they are working on their projects in the field.

8. Students' opinion will be considered in designing and updating the curriculum

In case of designing and updating curriculum, the students might have the opportunity to share ideas on how to make the curriculum more flexible in its application. With the involvement of the students, it helps the curriculum designers to develop curriculum contemporariness, up-to-date and useful for the students, educators, and stake holders as well.

\section{Students will become more independent in their own learning}

By "collaborative" learning, the students can express their ideas toward the course being studied. This condition will positively increase their creativity during the learning process. While teachers' role as facilitators will guide them any time they need through their learning process.

Qusthalani (rumah belajar Kementerian Pendidikan dan Kebudayaan; 2018) explains five competencies a teacher should prepare facing IR 4.0. They are: 1) internet educational competence based as a basic skill, 2) competence for technological commercialization; a competence that brings students to have entrepreneurship attitude by using technology for their best innovation, 3) competence in globalization where teachers aren't cultural stuttering and be to solve education problem at least in their classroom, 4) competence in future strategies; teachers' competence to predict what will happen in the future and the strategy to handle it such as joint lecture, jointresearch, joint-resources, staff mobility, or rotation, 5) counselor's competence; teachers' competence to realize that students' will face not only more difficulties in comprehending the subject matter, but also psychological aspect.

Those five competencies are not easy to implement. Recruitment is the first important aspect to consider. It has to follow standardized pattern where it is not only testing intellectual and psychological competences but also behavior of the candidate. These tests are aimed at teachers' readiness in facing education in the IR 4.0 era.

\section{c. Characteristics of Education Innovation in IR 4.0}

The application of educational innovation is aimed at all levels of education, from primary to higher one. Without considering to those differences, there are 10 characteristics on an innovative classroom (www.thetechadvocate.org).

\section{1) Reflection}

Innovative classroom needs continuously reflection. It is admitted that sometimes reflection in uncomfortable for students because they push themselves to ask questions and then learn more. However, reflection makes them understand how they feel and respond the learning.

2) Constant learning 
An innovative classroom never stops learning. As a simultaneous process, learning is something valuable for the students. They feel the excitement of the process since they can express themselves by doing something established with different procedure but introducing something new through collaborative project.

\section{3) Creativity}

A creative classroom not only comes up with unique solutions to everyday problems, but it also develops the responses necessary to deal with future challenges. It means that a creative classroom help the development of innovation by encouraging the students to think out of the box.

\section{4) Connection}

A teacher as an educator must always know his/her students well. In this case, he/she has to find out new techniques that encourage students do the same. With the connection between the teacher and the students, the learning will become enjoyable.

\section{5) Principles and routines}

In an innovative classroom, a teacher should consistent with the principles and routines as guideline on how the class runs. The teacher is someone whom students imitate, especially students at elementary level. He/she has to keep the regulation made and stick on it.

6) Problem finding

In case of problems, an innovative classroom does not wait any longer to solving them. The students used to be creative to find out solution of the problem by discussing it with their classmates. By starting with a question "why" or "how", they can investigate the core of the problem with their own way, then find the solution.

\section{7) Collaboration}

Innovation needs collaboration. An innovation classroom is essentially a collaborative class. In the collaborative class the students are used to discuss, and work with one another without caring any differences of one another. They also are familiar with class projects related to subject matters given by the teacher. With this work collaboration, they usually make innovation.

8) Variation

A teacher in the innovative classroom does not rely on one or two teaching techniques or strategies in his/her teaching process. Variation is very important in teaching. The teacher must be active and creative to find out new techniques or strategies and apply them from day to day to make the students enjoy the learning.

9) Goal setting 
An innovative classroom and innovative students will set their own goals. The goals can be small or large or in between. Those goals will guide them to set the program to achieve the target. At last, the goals will produce innovation.

10) Opportunities for revision

Nothing is perfect. Innovative classroom and students realize that they and the teacher are always charging, adapting, and improving themselves toward the very fast changing of IR 4.0. Thus, the teacher and the students have the opportunity to revise goals they have set in order to adjust with the latest trend.

We, now, realize that technology and information are overload in many aspects of life. Among those changing, education is part of them. In this case, students are part of them. Students, with all differences among them, included the way they are learning, need to be guided to develop their knowledge and skills. The students need to prepare themselves to face the industrial revolution which will happen in their life time (https://www.intelitek.com/what-is-education-4-0). The students have to practice subject matters they have taught and mastered more than the theories they have got. For doing them well, students need accessed information that they can learn it without depend much on the teacher.

\section{PROFESSIONAL TEACHER IN PRIMARY EDUCATION IN IR 4.0}

Marr (https://www.google.com/amp/s/www.forbes.com/sites/bernardmarr May 22 , 2019) said that the $4^{\text {th }}$ industrial revolution change so fast. It implicates the way we relate to one another, live, work, and educate our children. Technology in its so many kinds, types, and series of devices accelerates and simplifies everything in human's activities. Information communication is something else that every one, at anytime and anywhere needs to make them easier and accurate in anything they do. By those smart technology machines with the speed of world change, force our children to engage in those conditions. The consequence is that the students should be trained even educated harder than before in a different way from the past.

In accordance with education especially primary education in the era of industry 4.0 educators, schools, government officials, and parents must rethinking or revisit educational paradigm with the focus on the areas that needs rethinking. Besides, those stake holders should review the approach and or strategy to prepare the next generationmillennials--to the challenges of the dynamically world change. Thus, Marr suggests 8 things every school include primary education must do to prepare for the 4th industrial revolution:

a. Redefine the purpose of education

In today's world, educators and stake holders should redefine the education as a whole; the paradigm, the purpose, the program, the approach, even the strategy. Today's students should be prepared to face the challenges of IR 4.0. They have to take on the advantages of technology to solve problems in their career and life time. In this case, educators/teachers function as facilitator. Their major task is supporting and encouraging students to develop their skill and mindset to do something valuable by using technology positively. 
b. Improve STEM education

STEM stands for science, technology, engineering, and math. Nowadays, everything is easier because of the presence of technology based devices. It is no doubt that STEM is needed in many aspects of job and activities. In schools, educators need to improve some technical skills of STEM to students. Teachers help students understand the value of STEM, take advantage and use it ethically.

c. Develop human potential

It is already known and believed that machines can substitute and take over human's job. Machines are better at doing many tasks accurately. Nevertheless, the essential point is that machines cannot create anything, imagine, do social and physical interaction, and critical thinking as what human used to do.

d. Adapt to lifelong learning models

Ideally, education must become a lifelong learning model. Curiosity, creativity, critical thinking, and

work collaboration are essential in today's life. Those skills are needed in education model at IR 4.0 era. Thus, teacher should train those skills and competencies to students so that they can compete in this millennial era.

e. "If we teach today's students as we taught yesterday's, we rob them of tomorrow" (John Dewey)

The sentence uttered by Dewey above indicates that teachers are responsible to teach students in

skills/competence than theory, more collaborative work or project than individual one. While the teachers' roles

are more facilitator or mentor than lecturers, process of teaching is much more personalized supported by

bringing in technologies such as computer and other devices, and guiding students on their own learning and inquiry.

f. Allow students to be creative

Students in this technological era or IR 4.0 are encouraged to try and do something new in another way with another procedure or method by taking the advantages of technology, then produce or introducing something else better. They do understand that technology helps them much in doing their projects. In this case, schools need to provide students learning situations and environments that enable them to be creators using a wide variety of physical and digital tools. With this condition the students with the love of learning will make sense of their world by hands-on experiences with the emphasis on collaboration and creativity. Thus, stake holders and educators, ideally, give the students space to practice their competence and skill in problem solving, curiosity, and trial and error to come to the end that is innovation.

\section{g. International mindfulness}

In a digital, interconnected world with only in one finger, employees of the future need to have a global mindset. Schools and educators are the same. They have to 
prepare and train students with the digital based learning and make them familiar with that kind of learning environment. Such as, it is much better teaching English pronunciation by watching native speakers who have that language than teacher's drilling.

h. Change the way of learning in higher education

Especially higher education, the way of learning should be changed too. The students must be prepared to the demand of IR 4.0. Learning in higher education needs modification which is more focused on a life-learning education. It means that the learning is not only what it is in the curriculum, but also develops a love for learning during the students' life span.

Moreover, Education for All from UNESCO states that to be a professional teacher, he/she should have 4 competencies. Those are pedagogy, professional, personality, and social. These competencies are correlated to the characteristics of learning in the $21^{\text {st }}$ century; learning to know, learning to do, learning to be, and learning to live together.

1. Pedagogy

A teacher should know the pedagogical concept in teaching and learning. In this case, the teachers have to

master pedagogical competency as it is mentioned in Permendikbud No.16 Tahun 2007:

a. Master students' characteristic physically, moral, spiritual, social, cultural, emotional, and intellectual.

b. Master learning theory and principles of educative learning.

c. Develop curriculum related to subject matter.

d. Provide educative learning.

e. Use information technology and communication for teaching.

f. Facilitate students' potential development in order to actualize students' potency.

g. Communicate effectively, empathy and polite with students.

h. Provide assessment and evaluation of students' achievement

i. Use the result of the assessment and evaluation for learning.

j. Do reflective action to improve learning quality.

2. Professional

A teacher should be able to implement the concepts properly in the classroom. A professional competence means a set of competence and skill in mastering subject matter comprehensively. Thus, a professional teacher should master 1) subject matter, 2) manage teaching-learning program, 3) classroom management, 4) use media and learning source. According to (http://:www.dasarguru.com/kompetensiprofesional) a) develop standard competence and basic competence suitable to subject matter, b) master subject matter, concept, pattern, and science structure widely and deeply suitable to the subject matter, c) develop subject matter to the learning creatively, d) develop sustainable professionalism by carrying out reflective action (class action research).

3. Personality

A teacher should have a good personality. Personality competence as it is in UndangUndang Republik Indonesia Nomor 14 Tahun 2005 and government regulation Number 19 Tahun 2005 about Standard of National Educations in which individual's 
competence is like good character, authoritative, wise, tough and example for the students.

4. Social

A teacher should live together in the dynamic society. It means that a teacher can 1) communicate with students and their parents well, 2) sympathetic, 3) join school committee well, 4) have a good friendship with colleagues, and 5) understand the environment.

\section{CONCLUSION}

During the past decades, education experienced many changes and modifications from era 1.0 till 4.0. Along with the development of science and technology, now we are in the era of industrial revolution 4.0 towards the era of 5.0. As its name "industrial technology", human's jobs are substituted or replaced by machines. Many activities are based on technology. Even many problems can be solved by clicking only one finger with many kinds and series of devices. One of the characteristic of education in IR 4.0 is innovation. Education in IR 4.0 demands students to be creative, curious, collaborative work without paying attention to any differences among them. Students are eager and are encouraged to do something existed or established with different way or procedure to produce or introducing something new. It is innovation. Thus, educators/teachers and stake holders who are concerned with education, are responsible to prepare students to face the challenges of IR 4.0. They must develop the students' skills and competences by taking the advantages of the technology. It is a professional teacher/educator from primary to higher education who can do that. Education in IR 4.0 era needs professional teachers/educators who are willing to create smart millennial generations. A professional teacher or educator roles as a facilitator or a mentor who guides students to create innovation while still paying attention to their individual's unique. By understanding and applying the concept of pedagogy, professional, personality, and social and correlate to the characteristics of learning in the 21 st century; learning to know, learning to do, learning to be, and learning to live together, primary education will be ready to face the challenges of IR 4.0.

\section{REFERENCES}

http://:www.dasarguru.com/kompetensi-profesional

http://www.downes.ca/post/67693

http://www.freshconsulting.com/what-is-innovation

https://www.google.com/amp/s/www.forbes.com/sites/bernardmarr . May22, 2019

https://id.scribd.com/doc

https://www.intelitek.com/what-is-education-4-0/ International Journal of Education \& Literacy Studies ISSN: 2202-9478

Government Regulation Number 19 Tahun 2005 about Standard of National Education 
Hussin, Anealka Aziz. Education 4.0 Made Simple: Ideas For Teaching. www.ijels.aiac.org.au, International Journal of Education \& Literacy Studies. July 31, 2018 Volume: 6 Issue: 3. ISSN: 2202-9478

Mykhailsyin, Halyna; Kondur, Oksana; Serman, Lesia. Scientific Journal, http://jpnu.pu.if.ua vol. 5, No. 1 (2018), 9-16)

Rumah belajar Kementerian Pendidikan dan Kebudayaan (www.Kemdikbud.go.id, 10 Desember 2018)

pcf4.dec.uwi.edu>innovation

Permendikbud No.16 Tahun 2007

Undang-Undang Republik Indonesia Nomor 14 Tahun 2005

UNESCO: Education for All (EfA-UNESCO)

www.thetechadvocate.org 
